Research Article

\title{
Impact of Graded Levels of Dietary Protein on Elemental Concentra- tion of Genetically Improved Farmed Tilapia (GIFT) from Pakistan
}

\author{
Anila Kousar, Muhammad Naeem*, Samrah Masud, Abir Ishtiaq, Zara Naeem and Rabia Iqbal
}

Institute of Pure and Applied Biology (Zoology Division), Babauddin Zakariya University, Multan, Pakistan.

\begin{abstract}
The present investigation conducted in 90 days feeding trial evaluated the effect of three dietary protein feeds $(15 \% \mathrm{CP}, 20 \% \mathrm{CP}, 25 \% \mathrm{CP})$ composed of plant protein ingredients, on elemental concentration in Genetically Improved Farmed Tilapia (GIFT) fingerlings, a developed strain of Nile tilapia (Oreochromis niloticus). Feed preparation criteria was based on cost effectiveness and local availability of cheaper plant protein feed ingredients. Ten specimens were randomly selected from each treatment hapa for evaluating the concentrations of selected essential and non-essential elements in GIFT fingerlings fed with dietary protein levels of 15\% (T1), 20\% (T2) and 25\% (T3) crude protein. Flame Atomic Absorption Spectrometer was used for the analysis of whole-body elemental concentrations in relation to fish size under the influence of various dietary protein levels. The concentrations of $\mathrm{K}, \mathrm{Na}, \mathrm{Ca}, \mathrm{Mg}, \mathrm{Fe}, \mathrm{Zn}, \mathrm{Pb}$ and $\mathrm{Cd}$ were quantified for T1, T2 and T3 fish samples. An increasing trend was observed in the concentrations of studied elements with the increase of dietary crude protein in fish feed. The elemental concentration in the carcasses of studied GIFT yielded similar accumulation pattern for three treatment groups T1, T2 and T3, i.e., $\mathrm{K}>\mathrm{Na}>\mathrm{Ca}>\mathrm{Mg}>\mathrm{Fe}>\mathrm{Zn}>$ $\mathrm{Pb}>\mathrm{Cd}$. Linear and multiple regression was applied to check the significance of accumulated elements. The relationship among the element concentrations and weight and length of fishes was also examined. A positive association between the elements and weight and length of the sampled fish was noted except for Fe in $\mathrm{T} 1$ with body weight. A common trend of positive and negative allometry was observed for most of the elemental concentrations with wet body weight and total length respectively. The level of non-essential toxic elements, $\mathrm{Cd}$ and $\mathrm{Pb}$, did not exceed the permitted levels of international standard.

Received | May 22, 2021; Accepted | July 07, 2021; Published | August 24, 2021

*Correspondence | Muhammad Naeem, Institute of Pure and Applied Biology (Zoology Division), Bahauddin Zakariya University, Multan, Pakistan; Email: dr_naeembzu@yahoo.com

Citation | Kousar A., M. Naeem, S. Masud, A. Ishtiaq, Z. Naeem and Rabia Iqbal. 2021. Impact of graded levels of dietary protein on elemental concentration of Genetically Improved Farmed Tilapia (GIFT) from Pakistan. Sarhad Journal of Agriculture, 37(4): 1156-1166.

DOI | https://dx.doi.org/10.17582/journal.sja/2021/37.4.1156.1166

Keywords | Dietary protein, Elemental concentration, GIFT fingerlings, Hapas, Regression analysis
\end{abstract}

\section{Introduction}

I $n$ flourishing fish industry, one of the major impediment is the cost of fish feed ingredients of the total production budget (Cheikyula et al., 2020) because fish meal is the preferred gold standard component of fish feed but highly expensive and limited in supply (Radhakrishnan et al., 2016). Although, now it is considered both environmentally and ecologically unsustainable and requires to find alternative proteins December 2021 | Volume 37 | Issue 4 | Page 1156 due to economic pressure on the aquaculture industry (Turchini et al., 2019). For successful aquaculture, there is a need to replace fish meal for the preparation of fish feeds, particularly for omnivorous fish species. Plant based protein sources can cope the need of the time due to increasing fish culture as population is increasing day by day (Daniel, 2018; Zettle et al., 2019). Alternative plant protein sources like pulses, grains and oilseeds are widely used for economic fish feed preparations (Abdel-Warith et al., 2019). 
Fish is considered a very valuable source of protein and essential nutrients including minerals and vitamins for balanced nutrition and good health of humans (Ahmed et al., 2017; Bennett et al.,2018). They also possess polyunsaturated fatty acids which provide protection against cardiac issues. Improper handling in fisheries units and level of pollutants in fish demand attention because of adverse effects of pollutants on human health, the consumers of fish (Das et al.,2017).

Heavy metals are of particular concern due to their non-biodegradable nature and bioaccumulation ability. Heavy metals pollute the aquatic environment because these are toxic and become harmful for fish due to being accumulated and bio-magnified inhabiting such environments. Heavy metal pollution imposes dreadful consequences leading to disturbance in the equilibrium of environment and fish health (Adamu et al., 2016; Alhassan et al., 2016). However, the presence of heavy metals in fish, not only impairs the health of the consumers, but also obstruct the positive effect of beneficial elements. If accumulation of these elements is higher than the requirement of organisms, then deposition of such elements occur in their tissues (Aldogachi et al., 2016). These elements are metabolized to a limited extent because mostly heavy metals are unable to biodegrade (Rajkowska and Protasowicki, 2013) and thus have long lasting toxic effects (Sthanadar et al., 2015). Therefore, contamination due to heavy metals has adverse impact on the aquatic organisms as well as on the environment (Agrahari et al., 2017).

It is fact that all heavy metals are not lethal. Sodium is a principal positive ion in cells (Soetan et al., 2010). Calcium is a mineral that must be constantly taken up to build bone and maintain the blood level of calcium. Normal clotting of blood needs calcium. It is also required for muscle, neuron and cellular function. Many enzymes as well as carbohydrate and protein metabolism need magnesium (Soetan et al., 2010). Few heavy metals, such as iron and zinc act as trace elements and are vital for the maintenance of human metabolism and fish (Aziz et al., 2017). Iron is an integral component of haemoglobin, myoglobin, enzymes and cytochromes. Zinc is an essential element of many enzymes and metalloproteins in the metabolism of fish (Olsson et al., 1998).

Other metals, such as lead and cadmium do not have known role in the normal fish physiology and are non-essential metals (Hanan, 2007). Presence of cadmium, for a long time, in the bodies of animals and humans, can be carcinogenic (Jaishankar et al., 2014). It can cause severe pain in bones and lead to accumulation in kidneys and may be a cause of kidney failure (NIFES, 2016).Lead affects the children's intelligence and neurophysiological development (WHO, 1995).

Bio-accumulation of metals in the cultured fish occurs through the skin and gills by diffusion from the polluted water as well as with ingested food (Das et al., 2017). Deposition of metals above their threshold level, may cause stress and severely affect the fish physiology (Roy et al., 2011). Aquatic habitats deposit high amounts of metals in sediments and with the passage of time transfer to the fish (Shovon et al., 2017). Fish gills, gonads, kidney and liver accumulate more metals due to their active metabolism (Ahmed et al., 2017). Feed ingredients also have an imperative role in the aggregation of element components in the fish body (Iqbal et al., 2019).

The main objective of the current study was to evaluate the impact of three cost-benefit fish feeds composed of different combinations of plant protein-based ingredients on elemental concentration in GIFT fed with three different dietary proteins.

\section{Materials and Methods}

The current experimental work was carried out for 90 days at Tawakkal Fish Hatchery, Muzaffer Garh, South Punjab, Pakistan.

\section{Experimental layout and feed formulation}

The mono sex (male) Genetically Improved Farmed Tilapia (GIFT) fingerlings, an improved strain of Nile tilapia (Oreochromis niloticus), were selected for the evaluation of elemental concentration to check the influence of graded dietary protein feeds. Three crude protein feeds (15\% CP, 20\% CP, $25 \% \mathrm{CP}$ ) were fed to GIFT) fingerlings, after acclimatization for two weeks by feeding on fish meal @ 10\% fish body weight in cemented tanks. After acclimatization, fish specimens having mean initial weight of $1.61 \pm 0.08$ $\mathrm{g}$ and mean initial length $4.31 \pm 0.39 \mathrm{~cm}$ were transferred to hapas $(8 \times 6 \times 3 \mathrm{ft})$, placed in earthen ponds having water level of 3 to $4 \mathrm{ft}$, fed with experimental feed @ 5\% fish body weight. Feed was provided to GIFT fingerlings twice a day between 8:00-9:00 am and 7:00- 8:00 pm, for 90 days. 
Analysis of elemental concentration in GIFT

At the end of feeding trial, GIFT samples were packed in polythene bags filled with water and oxygen and transferred to fishery laboratory situated in Institute of Pure and Applied Biology (IP\&AB), Bahauddin Zakariya University, Multan (Pakistan). A total of 30 fish samples, 10 fish from each treatment group were randomly collected. Wet body weight and total length of all the collected fish samples were measured using digital electric balance (SHIMADZU ELB-300 Japan) to the nearest of 0.01g, and length (cm) measured using a scale. Each fish was placed on aluminum foil plate and dried (at $70^{\circ} \mathrm{C}$, whole fish) until a constant weight in drying oven (Memmert, W. Germany). After drying, pestle and mortar was used for grinding the whole fish samples to obtain its powder form.

Dried fish powder was ashed in muffle furnace at $500^{\circ} \mathrm{C}$ for 24 hours. One gram ash content of each fish sample was dissolved in $10 \mathrm{ml}$ solution of $70 \%$ $\mathrm{HNO}_{3}$ All samples were diluted using deionized water up to $25 \mathrm{ml}$ and filtered using Whatman 42 filter papers. Prepared samples were kept in the labelled plastic bottles. To analyze the elemental concentration in fish samples, a total of 8 essential and non-essential elements were selected. Atomic absorption spectrometer (Agilent 240 A A) was used to estimate the concentrations of sodium, calcium, magnesium, potassium, iron, zinc, lead and cadmium. Two replicate analyses were carried out for each and every sample. Concentrations of elements were computed using Spectr A A Software.

\section{Statistical analysis of data}

Mean values and their standard deviations were calculated for each element. Statistical analyses including regression, computation of correlations and standard error were applied using excel. Predictive models were developed using linear regression to check the significance of accumulated elements. MINITAB software was used for the analysis of multiple regression. $\mathrm{Re}^{-}$ gression analyses were performed between values of fish size and whole-body elemental concentration of the fish. As variations in elemental concentration are related to fish size, relationship between these variables was determined using the multiple regression equation given below:

$$
\mathrm{Y}=\mathrm{a}+\mathrm{b}_{1} \mathrm{~W}+\mathrm{b}_{2} \mathrm{TL}
$$

Where;

$\mathrm{Y}$ represents elements, wet body weight and total length are represented by $\mathrm{W}$ and TL, respectively, b1 and $\mathrm{b} 2$ are slopes and $\mathrm{a}$ is intercept.

Table 1: Values of grand means and standard deviations of elemental concentrations in carcasses of GIFT (Oreochromis niloticus, whole fish) $(n=10)$.

\begin{tabular}{|c|c|c|c|}
\hline Elements & Treatments & $\begin{array}{l}\text { Dry weight }(\mu \mathrm{g} / \mathrm{g}) \\
\text { Mean } \pm \text { S.D. }\end{array}$ & $\begin{array}{l}\text { Wet weight }(\mu \mathrm{g} / \mathrm{g}) \\
\text { Mean } \pm \text { S.D. }\end{array}$ \\
\hline $\mathrm{Na}$ & $\begin{array}{l}\text { T1 }(15 \%) \\
\text { T2 }(20 \%) \\
\text { T3 }(25 \%)\end{array}$ & $\begin{array}{l}4101.25 \pm 857.59 \\
4870.88 \pm 953.88 \\
5528.98 \pm 1691.43\end{array}$ & $\begin{array}{l}858.02 \pm 202.88 \\
966.20 \pm 192.76 \\
1195.32 \pm 405.17\end{array}$ \\
\hline $\mathrm{K}$ & $\begin{array}{l}\text { T1 }(15 \%) \\
\text { T2 }(20 \%) \\
\text { T3 }(25 \%)\end{array}$ & $\begin{array}{l}9090.00 \pm 1023.45 \\
9840.00 \pm 1048.26 \\
10137.50 \pm 2245.91\end{array}$ & $\begin{array}{l}1900.48 \pm 289.54 \\
2052.86 \pm 282.76 \\
2207.17 \pm 639.99\end{array}$ \\
\hline $\mathrm{Ca}$ & $\begin{array}{l}\text { T1 }(15 \%) \\
\text { T2 }(20 \%) \\
\text { T3 }(25 \%)\end{array}$ & $\begin{array}{l}5296.62 \pm 730.49 \\
6057.88 \pm 526.98 \\
7860.38 \pm 1147.83\end{array}$ & $\begin{array}{l}1104.69 \pm 172.78 \\
1202.04 \pm 130.32 \\
1687.23 \pm 282.15\end{array}$ \\
\hline $\mathrm{Mg}$ & $\begin{array}{l}\text { T1 }(15 \%) \\
\text { T2 }(20 \%) \\
\text { T3 }(25 \%)\end{array}$ & $\begin{array}{l}871.23 \pm 183.95 \\
989.04 \pm 163.53 \\
1349.04 \pm 216.59\end{array}$ & $\begin{array}{l}181.61 \pm 39.91 \\
195.47 \pm 27.02 \\
292.37 \pm 67.53\end{array}$ \\
\hline $\mathrm{Fe}$ & $\begin{array}{l}\text { T1 }(15 \%) \\
\text { T2 }(20 \%) \\
\text { T3 }(25 \%)\end{array}$ & $\begin{array}{l}607.67 \pm 386.56 \\
896.93 \pm 118.81 \\
921.38 \pm 257.49\end{array}$ & $\begin{array}{l}125.26 \pm 80.58 \\
178.56 \pm 30.77 \\
198.81 \pm 60.97\end{array}$ \\
\hline $\mathrm{Zn}$ & $\begin{array}{l}\text { T1 }(15 \%) \\
\text { T2 }(20 \%) \\
\text { T3 }(25 \%)\end{array}$ & $\begin{array}{l}169.33 \pm 47.57 \\
182.18 \pm 37.05 \\
206.83 \pm 20.32\end{array}$ & $\begin{array}{l}35.26 \pm 10.14 \\
36.32 \pm 8.32 \\
44.70 \pm 7.64\end{array}$ \\
\hline $\mathrm{Cd}$ & $\begin{array}{l}\text { T1 }(15 \%) \\
\text { T2 (20\%) } \\
\text { T3 (25\%) }\end{array}$ & $\begin{array}{l}0.41 \pm 0.85 \\
0.43 \pm 0.20 \\
0.46 \pm 0.18\end{array}$ & $\begin{array}{l}0.10 \pm 0.02 \\
0.10 \pm 0.04 \\
0.11 \pm 0.08\end{array}$ \\
\hline $\mathrm{Pb}$ & $\begin{array}{l}\text { T1 }(15 \%) \\
\text { T2 }(20 \%) \\
\text { T3 }(25 \%)\end{array}$ & $\begin{array}{l}1.45 \pm 0.42 \\
1.49 \pm 0.27 \\
1.65 \pm 0.39\end{array}$ & $\begin{array}{l}0.31 \pm 0.97 \\
0.30 \pm 0.05 \\
0.40 \pm 0.10\end{array}$ \\
\hline
\end{tabular}

S.D. $=$ Standard Deviation

\section{Results and Discussion}

The mean values and standard deviations of various elemental concentrations observed on the basis of wet and dry weight in the carcasses of farm-raised GIFT are summarized in Table 1 . In the present study, on the basis of obtained results, the accumulation pattern of studied elements in the treated GIFT in descending order, on dry and wet weight basis, was as follows: $\mathrm{K}>$ $\mathrm{Na}>\mathrm{Ca}>\mathrm{Mg}>\mathrm{Fe}>\mathrm{Zn}>\mathrm{Pb}>\mathrm{Cd}$. These results indicate that concentration of potassium $(\mathrm{K})$ was highest in the studied GIFT (O. niloticus) samples than any other element. The maximum concentration value of $\mathrm{K}$ in the GIFT belonging to treatment group fed with 25\% CP diet (T3) was $10137.50 \pm 2245.91 \mu \mathrm{g} / \mathrm{g}$ and $2207.17 \pm 639.99 \mu \mathrm{g} / \mathrm{g}$ on dry and wet weight basis, respectively. Whereas the minimum recorded 
Table 2: Relationship between log-transformed data of body burden element $(\mu g / g)$ and wet body weight $(g)$ of GIFT (Oreochromis niloticus) ( $n=10)$.

\begin{tabular}{|c|c|c|c|c|c|c|}
\hline Elements & Treatments & Correlation coefficient $(r)$ & Intercept (a) & Slope (b) & Standard Error (b) & $t$-value when $b=1$ \\
\hline $\mathrm{Na}$ & $\begin{array}{l}\text { T1 }(15 \%) \\
\text { T2 }(20 \%) \\
\text { T3 }(25 \%)\end{array}$ & $\begin{array}{l}0.930^{* * *} \\
0.778^{* *} \\
0.866^{* *}\end{array}$ & $\begin{array}{l}0.889 \\
2.156 \\
1.429\end{array}$ & $\begin{array}{l}2.795 \\
1.768 \\
2.383\end{array}$ & $\begin{array}{l}0.389 \\
0.504 \\
0.485\end{array}$ & $\begin{array}{l}7.173 \\
3.505 \\
4.909\end{array}$ \\
\hline K & $\begin{array}{l}\text { T1 }(15 \%) \\
\text { T2 }(20 \%) \\
\text { T3 }(25 \%)\end{array}$ & $\begin{array}{l}0.896^{* * * *} \\
0.860^{* * *} \\
0.937^{* * * *}\end{array}$ & $\begin{array}{l}2.238 \\
3.137 \\
1.356\end{array}$ & $\begin{array}{l}1.915 \\
1.141 \\
2.672\end{array}$ & $\begin{array}{l}0.336 \\
0.239 \\
0.352\end{array}$ & $\begin{array}{l}5.705 \\
4.770 \\
7.594\end{array}$ \\
\hline $\mathrm{Ca}$ & $\begin{array}{l}\text { T1 }(15 \%) \\
\text { T2 }(20 \%) \\
\text { T3 }(25 \%)\end{array}$ & $\begin{array}{l}0.749^{*} \\
0.718^{*} \\
0.922^{* * *}\end{array}$ & $\begin{array}{l}2.560 \\
3.123 \\
2.207\end{array}$ & $\begin{array}{l}1.422 \\
0.958 \\
1.860\end{array}$ & $\begin{array}{l}0.445 \\
0.328 \\
0.275\end{array}$ & $\begin{array}{l}3.199 \\
2.919 \\
6.754\end{array}$ \\
\hline $\mathrm{Mg}$ & $\begin{array}{l}\text { T1 }(15 \%) \\
\text { T2 }(20 \%) \\
\text { T3 }(25 \%)\end{array}$ & $\begin{array}{l}0.721^{*} \\
0.794^{* *} \\
0.761^{*}\end{array}$ & $\begin{array}{l}2.121 \\
1.777 \\
1.681\end{array}$ & $\begin{array}{l}1.268 \\
1.477 \\
1.657\end{array}$ & $\begin{array}{l}1.101 \\
0.399 \\
0.499\end{array}$ & $\begin{array}{l}1.152 \\
3.698 \\
3.319\end{array}$ \\
\hline $\mathrm{Fe}$ & $\begin{array}{l}\text { T1 }(15 \%) \\
\text { T2 }(20 \%) \\
\text { T3 }(25 \%)\end{array}$ & $\begin{array}{l}0.191^{\text {ns }} \\
0.503^{\text {ns }} \\
0.858^{* *}\end{array}$ & $\begin{array}{l}4.322 \\
2.439 \\
0.729\end{array}$ & $\begin{array}{l}-1.039 \\
0.819 \\
2.317\end{array}$ & $\begin{array}{l}1.892 \\
0.497 \\
0.491\end{array}$ & $\begin{array}{l}-0.549 \\
1.648 \\
4.719\end{array}$ \\
\hline $\mathrm{Zn}$ & $\begin{array}{l}\text { T1 }(15 \%) \\
\text { T2 }(20 \%) \\
\text { T3 }(25 \%)\end{array}$ & $\begin{array}{l}0.832^{* *} \\
0.067^{\text {ns }} \\
0.808^{* *}\end{array}$ & $\begin{array}{l}-0.709 \\
2.483 \\
0.985\end{array}$ & $\begin{array}{l}2.975 \\
0.128 \\
1.558\end{array}$ & $\begin{array}{l}0.702 \\
0.667 \\
0.402\end{array}$ & $\begin{array}{l}4.241 \\
0.191 \\
3.874\end{array}$ \\
\hline $\mathrm{Cd}$ & $\begin{array}{l}\text { T1 }(15 \%) \\
\text { T2 }(20 \%) \\
\text { T3 }(25 \%)\end{array}$ & $\begin{array}{l}0.671^{*} \\
0.190^{\text {ns }} \\
0.714^{*}\end{array}$ & $\begin{array}{l}-1.401 \\
-0.990 \\
-3.799\end{array}$ & $\begin{array}{l}1.364 \\
0.925 \\
3.363\end{array}$ & $\begin{array}{l}0.532 \\
1.685 \\
1.166\end{array}$ & $\begin{array}{l}2.563 \\
0.549 \\
2.884\end{array}$ \\
\hline $\mathrm{Pb}$ & $\begin{array}{l}\text { T1 }(15 \%) \\
\text { T2 }(20 \%) \\
\text { T3 }(25 \%)\end{array}$ & $\begin{array}{l}0.177^{\text {ns }} \\
0.815^{* *} \\
0.918^{* * * * *}\end{array}$ & $\begin{array}{l}0.022 \\
-1.347 \\
-1.906\end{array}$ & $\begin{array}{l}0.515 \\
1.766 \\
2.266\end{array}$ & $\begin{array}{l}1.013 \\
0.444 \\
0.346\end{array}$ & $\begin{array}{l}0.508 \\
3.977 \\
6.549\end{array}$ \\
\hline
\end{tabular}

Non-Significant $=n s,{ }^{*} P<0.05,{ }^{* * *} P<0.01$, ${ }^{* * 0 * *} P<0.001$.

concentration of $\mathrm{Cd}$ amounted to $0.41 \pm 0.85 \mu \mathrm{g} / \mathrm{g}$ in sampled GIFT belonging to treatment group fed with $15 \% \mathrm{CP} \operatorname{diet}(\mathrm{T} 1)$ on dry weight basis and 0.10 $\pm 0.02 \mu \mathrm{g} / \mathrm{g}$ and $0.10 \pm 0.04 \mu \mathrm{g} / \mathrm{g}$ on wet weight basis in $\mathrm{T} 1$ and $\mathrm{T} 2$ treatment groups, respectively. An increasing trend in the elemental concentration was noted in the treated fish with the increasing dietary proteins level $(25 \% \mathrm{CP}>20 \% \mathrm{CP}>15 \% \mathrm{CP})$.

\section{Relationship between fish body weight and elemental concentration}

In GIFT samples, values of correlation coefficient ' $r$ ' showed diverse correlation among various log-transformed values of elements and fish weight in three treatments groups (Table 2). In the present study, sodium, potassium and magnesium were found to show positive allometry with increasing body weight in all the treatment groups as the value of slope $b$ was more than 1 . While The studied GIFT fed with $15 \%$ and $25 \% \mathrm{CP}$ diet showed positive allometry in calcium, zinc and cadmium, but negative allometry $(\mathrm{b}<1)$ in $20 \%$ fed GIFT. Iron showed isometry in 15\% CP fed fish (T1) and positive allometry in 25\% CP fed fish (T3), but negative allometry was found in 20\% CP fed GIFT (T2). Lead yielded negative allometry in T1, but positive allometry in T2 and T3 GIFT. The regression parameters of the relationships between $\log$-transformed data of elemental concentrations and fish body weight are given in Table 2 .

\section{Relationship between total length and elemental concen- tration}

Regression analysis to assess the total length dependence of these elements revealed weak correlation between $\log$ transformed data of total length and most of the essential metals in three treated groups (Table 3). The relationship between total length and concentrations of $\mathrm{Fe}$ in $\mathrm{T} 1$ and $\mathrm{Cd}$ was found to be non-significant in T1, T2 and T3. Lead had non-significant relationship in T1, while having significant relationship in T2 and T3 fish.

As variations were observed to be related to the total length of the body, regression analysis revealed that the slope ' $b$ ' value of $\log$-log regression of the relationship between total length and total metal body burden was less than $3(\mathrm{~b}<3)$ exhibiting negative allometry in T1, T2 and T3 fish, except for $\mathrm{Na}$ and $\mathrm{Pb}$ 
Table 3: Relationship between log-transformed data of body burden element ( $\mu \mathrm{g} / \mathrm{g}$ ) and total length (cm) of GIFT (Oreochromis niloticus) $(n=10)$.

\begin{tabular}{|c|c|c|c|c|c|c|}
\hline Elements & Treatments & Correlation coefficient $(\mathbf{r})$ & Intercept (a) & Slope (b) & Standard error $b$ & $t$-value when $b=3$ \\
\hline $\mathrm{Na}$ & $\begin{array}{l}\text { T1 }(15 \%) \\
\text { T2 }(20 \%) \\
\text { T3 }(25 \%)\end{array}$ & $\begin{array}{l}0.721^{*} \\
0.815^{* *} \\
0.869^{* *}\end{array}$ & $\begin{array}{l}1.242 \\
0.273 \\
1.345\end{array}$ & $\begin{array}{l}2.829 \\
3.103 \\
2.819\end{array}$ & $\begin{array}{l}0.960 \\
0.781 \\
0.569\end{array}$ & $\begin{array}{l}2.947 \\
3.974 \\
4.959\end{array}$ \\
\hline $\mathrm{K}$ & $\begin{array}{l}\text { T1 }(15 \%) \\
\text { T2 }(20 \%) \\
\text { T3 }(25 \%)\end{array}$ & $\begin{array}{l}0.559^{\text {ns }} \\
0.795^{* *} \\
0.872^{* * *}\end{array}$ & $\begin{array}{l}2.854 \\
2.625 \\
1.454\end{array}$ & $\begin{array}{l}1.563 \\
1.783 \\
2.935\end{array}$ & $\begin{array}{l}0.818 \\
0.481 \\
0.582\end{array}$ & $\begin{array}{l}1.911 \\
3.705 \\
5.046\end{array}$ \\
\hline $\mathrm{Ca}$ & $\begin{array}{l}\text { T1 }(15 \%) \\
\text { T2 }(20 \%) \\
\text { T3 }(25 \%)\end{array}$ & $\begin{array}{l}0.666^{*} \\
0.709^{*} \\
0.931^{* * * *}\end{array}$ & $\begin{array}{l}2.529 \\
2.574 \\
2.126\end{array}$ & $\begin{array}{l}1.652 \\
1.620 \\
2.217\end{array}$ & $\begin{array}{l}0.653 \\
0.570 \\
0.307\end{array}$ & $\begin{array}{l}2.529 \\
2.842 \\
7.221\end{array}$ \\
\hline $\mathrm{Mg}$ & $\begin{array}{l}\text { T1 }(15 \%) \\
\text { T2 }(20 \%) \\
\text { T3 }(25 \%)\end{array}$ & $\begin{array}{l}0.377^{\text {ns }} \\
0.775^{* *} \\
0.656^{*}\end{array}$ & $\begin{array}{l}2.121 \\
0.959 \\
1.904\end{array}$ & $\begin{array}{l}1.268 \\
2.468 \\
1.686\end{array}$ & $\begin{array}{l}1.101 \\
0.712 \\
0.685\end{array}$ & $\begin{array}{l}1.152 \\
3.467 \\
2.461\end{array}$ \\
\hline $\mathrm{Fe}$ & $\begin{array}{l}\text { T1 }(15 \%) \\
\text { T2 (20\%) } \\
\text { T3 }(25 \%)\end{array}$ & $\begin{array}{l}0.251^{\text {ns }} \\
0.496^{\text {ns }} \\
0.863^{* *}\end{array}$ & $\begin{array}{l}0.883 \\
1.989 \\
0.726\end{array}$ & $\begin{array}{l}0.035 \\
1.366 \\
2.664\end{array}$ & $\begin{array}{l}0.048 \\
0.845 \\
0.619\end{array}$ & $\begin{array}{l}0.734 \\
1.617 \\
4.303\end{array}$ \\
\hline $\mathrm{Zn}$ & $\begin{array}{l}\text { T1 }(15 \%) \\
\text { T2 (20\%) } \\
\text { T3 }(25 \%)\end{array}$ & $\begin{array}{l}0.725^{*} \\
0.805^{* *} \\
0.761^{*}\end{array}$ & $\begin{array}{l}0.581 \\
2.369 \\
1.045\end{array}$ & $\begin{array}{l}0.155 \\
0.258 \\
1.732\end{array}$ & $\begin{array}{l}0.052 \\
1.127 \\
0.523\end{array}$ & $\begin{array}{l}2.973 \\
0.228 \\
3.313\end{array}$ \\
\hline $\mathrm{Cd}$ & $\begin{array}{l}\text { T1 }(15 \%) \\
\text { T2 }(20 \%) \\
\text { T3 }(25 \%)\end{array}$ & $\begin{array}{l}0.505^{\text {ns }} \\
0.137^{\text {ns }} \\
0.541^{\text {ns }}\end{array}$ & $\begin{array}{l}0.966 \\
-1.094 \\
-2.923\end{array}$ & $\begin{array}{l}0.190 \\
1.125 \\
3.009\end{array}$ & $\begin{array}{l}0.115 \\
2.877 \\
1.653\end{array}$ & $\begin{array}{l}1.654 \\
0.391 \\
1.821\end{array}$ \\
\hline $\mathrm{Pb}$ & $\begin{array}{l}\text { T1 }(15 \%) \\
\text { T2 (20\%) } \\
\text { T3 }(25 \%)\end{array}$ & $\begin{array}{l}0.103^{\text {ns }} \\
0.837^{* *} \\
0.856^{* *}\end{array}$ & $\begin{array}{l}0.977 \\
-2.438 \\
-1.777\end{array}$ & $\begin{array}{l}0.027 \\
3.067 \\
2.478\end{array}$ & $\begin{array}{l}0.093 \\
0.709 \\
0.542\end{array}$ & $\begin{array}{l}0.292 \\
4.323 \\
4.575\end{array}$ \\
\hline
\end{tabular}

Non-Significant $=n s,{ }^{*} P<0.05,{ }^{* * *} P<0.01,{ }^{* * * * * *} P<0.001$.

in T2 and Cd in T3 GIFT fed with 20\% and 25\% dietary proteins, respectively, showing isometric increase with total length. Regression parameters of all these relationships are summarized in Table 3.

\section{Multiple Regression Analysis (MRA)}

When multiple predictive equations were applied to determine elemental concentrations in fish body weight and total length, significant correlations were observed in most of the cases (Table 4).

For the people of impoverished third world countries, fish is considered a cheap source among animal proteins. It is considered as a main source of many minerals that are very important for humans (E1-Shehawy et al., 2016). The mean concentrations of essential and non-essential elements obtained in GIFT ( $O$. niloticus) showed similarities as well as variations in comparison with the values already reported in the literature for the same and other fish species. These inter-specific variations may be related to the nature of their habitat, feeding habits (Ansari et al., 2006; Jim et al., 2017), season (Obot et al., 2016) and the differences in ecological requirements, swimming be- haviours and the metabolic activities among different fish species (Kalay et al., 1999). On the basis of results of present study, the accumulation order of elements in studied GIFT was: $\mathrm{K}>\mathrm{Na}>\mathrm{Ca}>\mathrm{Mg}>\mathrm{Fe}>\mathrm{Zn}>$ $\mathrm{Pb}>\mathrm{Cd}$; this trend is in agreement with the findings of Tsegay et al. (2016) in O. niloticus although $\mathrm{Cd}$ and $\mathrm{Pb}$ was not considered in their investigation. Iqbal et al. (2019) has reported same accumulation pattern of all these elements $(\mathrm{K}>\mathrm{Ca}>\mathrm{Na}>\mathrm{Mg}>\mathrm{Fe}>\mathrm{Zn}>\mathrm{Pb}>$ $\mathrm{Cd}$ ), in the whole fish body of hybrid (Catla $\mathrm{x}$ Labeo), except for $\mathrm{Ca}$ which showed higher levels than $\mathrm{Na}$. Similar pattern of elemental accumulation was also reported by Naeem et al. (2010) in O. mykiss, except for $\mathrm{Ca}$ which was highest in their study. Potassium is found to be the most abundant element in GIFT (O. niloticus) and this observation is supported by the results of Adefemi (2011) who had reported potassium as the most abundant metal in all the fish samples of Tilapia mosambis and is not known to be toxic to fish. The bio-accumulation of $\mathrm{K}$ could be very beneficial to man since they are essential minerals in human nutrition (Adeyeye, 1996). Jim et al. (2017) had also reported maximum concentrations of $\mathrm{K}$ in $\mathrm{O}$. niloticus studied from different ecological regions. Observed 
Table 4: Multiple regression analysis data concerning wet body weight $(W, g)$ and total length $(T L, \mathrm{~cm})$ with element concentration (wet body weight, $\mu g g^{-1}$ ) for GIFT (Oreochromis niloticus) $(n=10)$.

\begin{tabular}{|c|c|c|c|c|c|c|}
\hline Relationships & Treatments & $\mathbf{r}$ & b & $b_{1} \pm S . E$ & $b_{2} \pm$ S.E. & $\mathbf{r}^{2}$ \\
\hline $\mathrm{K}=\mathrm{a}+\mathrm{b}_{1} \mathrm{~W}+\mathrm{b}_{2} \mathrm{TL}$ & $\begin{array}{l}\text { T1 }(15 \%) \\
\text { T2 }(20 \%) \\
\text { T3 }(25 \%)\end{array}$ & $\begin{array}{l}0.797^{* *} \\
0.421 \mathrm{~ns} \\
0.893^{* * * *}\end{array}$ & $\begin{array}{l}949 \\
3068 \\
-857\end{array}$ & $\begin{array}{l}199.5 \pm 62.0 \\
194 \pm 169 \\
381 \pm 159\end{array}$ & $\begin{array}{l}-179 \pm 112 \\
-365 \pm 360 \\
-256 \pm 264\end{array}$ & $\begin{array}{l}0.635 \\
0.177 \\
0.797\end{array}$ \\
\hline $\mathrm{Na}=\mathrm{a}+\mathrm{b}_{1} \mathrm{~W}+\mathrm{b}_{2} \mathrm{TL}$ & $\begin{array}{l}\text { T1 }(15 \%) \\
\text { T2 (20\%) } \\
\text { T3 }(25 \%)\end{array}$ & $\begin{array}{l}0.842^{* *} \\
0.611 \mathrm{~ns} \\
0.755^{*}\end{array}$ & $\begin{array}{l}-518 \\
-1521 \\
-1100\end{array}$ & $\begin{array}{l}106.2 \pm 38.7 \\
-117 \pm 178 \\
-27 \pm 147\end{array}$ & $\begin{array}{l}-7.4 \pm 70.0 \\
412 \pm 378 \\
253 \pm 243\end{array}$ & $\begin{array}{l}0.709 \\
0.373 \\
0.570\end{array}$ \\
\hline $\mathrm{Ca}=\mathrm{a}+\mathrm{b}_{1} \mathrm{~W}+\mathrm{b}_{2} \mathrm{TL}$ & $\begin{array}{l}\text { T1(15\%) } \\
\text { T2(20\%) } \\
\text { T3(25\%) }\end{array}$ & $\begin{array}{l}0.404 \mathrm{~ns} \\
0.481 \mathrm{~ns} \\
0.791^{* *}\end{array}$ & $\begin{array}{l}353 \\
809 \\
32\end{array}$ & $\begin{array}{l}-2.9 \pm 56.0 \\
-63 \pm 152 \\
-8.4 \pm 95.4\end{array}$ & $\begin{array}{l}80 \pm 101 \\
121 \pm 323 \\
167 \pm 158\end{array}$ & $\begin{array}{l}0.163 \\
0.256 \\
0.625\end{array}$ \\
\hline $\mathrm{Mg}=\mathrm{a}+\mathrm{b}_{1} \mathrm{~W}+\mathrm{b}_{2} \mathrm{TL}$ & $\begin{array}{l}\text { T1(15\%) } \\
\text { T2(20\%) } \\
\text { T3(25\%) }\end{array}$ & $\begin{array}{l}0.588 \mathrm{~ns} \\
0.481 \mathrm{~ns} \\
0.604 \mathrm{~ns}\end{array}$ & $\begin{array}{l}152 \\
71 \\
275\end{array}$ & $\begin{array}{l}21.8 \pm 11.4 \\
7.9 \pm 27.7 \\
55.0 \pm 29.7\end{array}$ & $\begin{array}{l}-27.2 \pm 20.7 \\
3.2 \pm 58.9 \\
-76.8 \pm 49.3\end{array}$ & $\begin{array}{l}0.346 \\
0.231 \\
0.365\end{array}$ \\
\hline $\mathrm{Fe}=\mathrm{a}+\mathrm{b}_{1} \mathrm{~W}+\mathrm{b}_{2} \mathrm{TL}$ & $\begin{array}{l}\text { T1(15\%) } \\
\text { T2(20\%) } \\
\text { T3(25\%) }\end{array}$ & $\begin{array}{l}0.819^{* *} \\
0.028 \mathrm{~ns} \\
0.681^{*}\end{array}$ & $\begin{array}{l}-190 \\
184 \\
-92\end{array}$ & $\begin{array}{l}-55.5 \pm 16.4 \\
-4.0 \pm 35.7 \\
7.1 \pm 24.6\end{array}$ & $\begin{array}{l}108.5 \pm 29.6 \\
4.4 \pm 75.9 \\
17.1 \pm 40.9\end{array}$ & $\begin{array}{l}0.670 \\
0.0008 \\
0.465\end{array}$ \\
\hline $\mathrm{Zn}=\mathrm{a}+\mathrm{b}_{1} \mathrm{~W}+\mathrm{b}_{2} \mathrm{TL}$ & $\begin{array}{l}\text { T1 }(15 \%) \\
\text { T2 }(20 \%) \\
\text { T3 }(25 \%)\end{array}$ & $\begin{array}{l}0.685^{*} \\
0.414 \mathrm{~ns} \\
0.471 \mathrm{~ns}\end{array}$ & $\begin{array}{l}-29.9 \\
52.6 \\
30.1\end{array}$ & $\begin{array}{l}3.18 \pm 2.62 \\
-3.93 \pm 8.83 \\
3.32 \pm 3.72\end{array}$ & $\begin{array}{l}2.19 \pm 4.73 \\
3.2 \pm 18.8 \\
-3.38 \pm 6.18\end{array}$ & $\begin{array}{l}0.469 \\
0.171 \\
0.222\end{array}$ \\
\hline $\mathrm{Cd}=\mathrm{a}+\mathrm{b}_{1} \mathrm{~W}+\mathrm{a}+\mathrm{b}_{2} \mathrm{TL}$ & $\begin{array}{l}\text { T1(15\%) } \\
\text { T2(20\%) } \\
\text { T3(25\%) }\end{array}$ & $\begin{array}{l}0.767^{\text {** }} \\
0.336 \mathrm{~ns} \\
0.869^{* *}\end{array}$ & $\begin{array}{l}0.07 \\
-0.43 \\
-079\end{array}$ & $\begin{array}{l}0.003 \pm 0.006 \\
0.042 \pm 0.045 \\
0.087 \pm 0.021\end{array}$ & $\begin{array}{l}-0.0002 \pm 0.011 \\
-0.089 \pm 0.095 \\
-0.121 \pm 0.034\end{array}$ & $\begin{array}{l}0.589 \\
0.113 \\
0.756\end{array}$ \\
\hline $\mathrm{Pb}=\mathrm{a}+\mathrm{b}_{1} \mathrm{~W}+\mathrm{b}_{2} \mathrm{TL}$ & $\begin{array}{l}\text { T1 }(15 \%) \\
\text { T2 (20\%) } \\
\text { T3 }(25 \%)\end{array}$ & $\begin{array}{l}0.754^{*} \\
0.621 \mathrm{~ns} \\
0.843^{* *}\end{array}$ & $\begin{array}{l}0.538 \\
-0.296 \\
-0.027\end{array}$ & $\begin{array}{l}-0.0093 \pm 0.034 \\
-0.0155 \pm 0.049 \\
0.0615 \pm 0.029\end{array}$ & $\begin{array}{l}-0.0100 \pm 0.061 \\
0.083 \pm 0.105 \\
-0.0481 \pm 0.049\end{array}$ & $\begin{array}{l}0.569 \\
0.386 \\
0.712\end{array}$ \\
\hline
\end{tabular}

Multiple correlation coefficient ( $r$ ), intercept (a), Regression coefficient (b1, b2), Standard error (S.E.), Non-significant $(n s),{ }^{*} P<0.05 .{ }^{* *} P$ $<0.01,{ }^{* * * * *} P<0.001$

levels of $\mathrm{Na}$ in the present study are in line with the reported values of Salam et al. (1993) in Labeo rohita but higher than Salam et al. (1996) and Tsegay et al. (2016) in O. niloticus. The obtained levels of $\mathrm{Ca}$ in studied GIFT are in agreement with Salam et al. (1993) in Labeo rohita but is lower than the reported value by Salam et al. (1996) in O. niloticus. Magnesium concentration in studied GIFT (T3) is similar to the findings of Salam et al. (1996) in O. niloticus and Naeem et al. (2010) in Aristicbthys nobilis but is lower than the value reported by Salam et al. (1993) in $L$. rohita. Naeem et al. (2012a) had reported much higher level of Mg in Mystus bleekeri. Adefemi (2011) had also reported higher concentrations of $\mathrm{K}, \mathrm{Na}, \mathrm{Ca}$ and $\mathrm{Mg}$ in Tilapia mosambis similar to the findings of the present study. This similarity in body concentrations suggest that the incorporation of essential elements into the body from dietary and waterborne sources is closely regulated (Shearer, 1984).

The higher concentrations of $\mathrm{Fe}$ and $\mathrm{Zn}$ observed in this study may be because of their essential role in fish metabolism. The international standards for $\mathrm{Zn}$ range are approximately 192-480 $\mu \mathrm{g} / \mathrm{g}$ (Yamazaki et al., 1996). The observed values of $\mathrm{Zn}$ concentration $(\mathrm{T} 1, \mathrm{~T} 2, \mathrm{~T} 3)$ observed in the present study are within the international standard range. The whole-body $\mathrm{Fe}$ concentration is higher than $\mathrm{Zn}(\mathrm{Fe}>\mathrm{Zn})$ in studied GIFT. Merciai et al. (2014) observed higher concentrations of Fe than $\mathrm{Zn}$ in the muscles of the fish they studied. Similarly, Jakhrani et al. (2017) had reported higher levels of $\mathrm{Fe}$ than $\mathrm{Zn}$ in homogeneous and dried samples of liver, gills and muscles of L. rohita and Cirrbinus mrigala. Mannan et al. (2018) studied the bioaccumulation of heavy metals in fish before and after feeding with synthetic feed for six months and reported higher levels of $\mathrm{Cu}, \mathrm{Cr}, \mathrm{Cd}, \mathrm{Pb}, \mathrm{Fe}$ and $\mathrm{Zn}$. Metal accumulation in these fish tissues varies according to the rates of uptake, storage and elimination (Langston, 1990). It is also known that the metabolic activity of younger individual is normally higher than that of an older individual which may lead to more metal accumulation (Widianarko et al., 2000). Different levels of heavy metals accumulate in different organs which could be attributed to the variations in their physiological roles to maintain home- 
ostasis, feeding habit, regulatory ability and behaviour of each fish (Adaka et al., 2017) and may contribute to whole body concentrations of various metals.

Cadmium is not essential for fish and its contamination in fish diet induces hazardous effects leading to retarded growth and abnormal protein pattern, such as in Nile tilapia (El-Serafy et al., 2013). The acceptable level of Cd is $0.5 \mu \mathrm{g} / \mathrm{g}(\mathrm{FAO}, 1983)$ cited in Ada$\mathrm{ka}$ et al. (2017). The obtained levels of Cd in the present study had low mean values. Ayeloja et al. (2014) had also reported lowest concentration of $\mathrm{Cd}$ in $O$. niloticus from Eleyele reservoir, Nigeria, as compared to other studied fishes in the same habitat. The range of $\mathrm{Pb}$ concentrations in $\mathrm{T} 1, \mathrm{~T} 2$ and $\mathrm{T} 3$ is below the permitted level of $\mathrm{Pb}(2.0 \mu \mathrm{g} / \mathrm{g})$ in fish flesh (FAO, 2010). Iqbal et al. (2019) has also reported mean $\mathrm{Cd}$ and $\mathrm{Pb}$ concentrations with in normal range in hybrid (Catla catla $\mathrm{x}$ Labeo rohita) fed on 15\%, 20\% and 25\% dietary protein levels of plant origin.

\section{Effect of body weight of fish on elemental concentration} Influence of fish body weight on whole body elemental concentration exhibited positive correlation, except for Fe in 15\% fed fish (T1) and this observation agrees with some previous reports (Salam et al., 2002; Ansari et al., 2006; Naeem et al., 2010; Fand, 2011). In the present study, $\mathrm{Na}, \mathrm{K}, \mathrm{Mg}$ in $\mathrm{T} 1, \mathrm{~T} 2$ and $\mathrm{T} 3$ while calcium in $\mathrm{T} 1$ and $\mathrm{T} 3$, and $\mathrm{Pb}$ in $\mathrm{T} 2$ andT3 exhibited positive allometry in relation to wet body weight in studied GIFT. These findings are in agreement with Salam et al. (1996) in O. nilotica for $\mathrm{Na}, \mathrm{K}$ and $\mathrm{Pb}$ showing positive allometry with body weight. The present study also revealed negative allometry in $\mathrm{Ca}$ and $\mathrm{Zn}$ (T2), $\mathrm{Cd}$ (T2) and $\mathrm{Pb}$ (T1) and isometric increase in $\mathrm{Fe}$ (T1) in relation to body weight and this is in general agreement with Naeem et al. (2010) report on Onchorynchus mykiss. Negative allometry in whole body $\mathrm{Zn}$ with body weight also coincides with results of Naeem et al. (2012 a) in $M$. bleekeri. Positive allometric increase in $\mathrm{Fe}$ in $\mathrm{T} 3$ indicating significant proportional increase is in agreement with Naeem et al. (2011) in A. nobilis. Report of Ansari et al. (2006) indicating positive allometry in $\mathrm{Ca}$, negative allometric growth in $\mathrm{Fe}$ and $\mathrm{Zn}$ in Puntius chola is in line with positive allometry in $\mathrm{Ca}(\mathrm{T} 1, \mathrm{~T} 3)$ and negative allometry in Fe and $\mathrm{Zn}$ (T2) in GIFT in relation to body weight. Significant proportional increase in $\mathrm{Zn}(\mathrm{T} 1, \mathrm{~T} 3)$ indicating positive allometry with body weight agrees with result of Naeem et al. (2012a) in $M$. bleekeri. These variations may be due to differences in foraging methods, metabolic rates and size of fish (Naeem et al., 2011) age, geographical distribution, and species-specific factors (Bawuro et al., 2018).

Cadmium showed least significant correlation with body weight and positive allometry in $\mathrm{T} 1$ and $\mathrm{T} 3$ fish, whereas, insignificant relation with body weight and negative allometry in T2 coincides with observations of Naeem et al. (2012 a) in Mystus bleekeri. This observation also agrees with reports of negative allometry between whole body $\mathrm{Cd}$ and body weight in O. mykiss and A. nobilis (Naeem et al., 2010, 2011). A non-significant relationship between $\mathrm{Pb}$ and body weight in T1, significant in T2 and highly significant correlation in T3 fish was observed. Lead exhibited negative allometry in $\mathrm{T} 1$ and positive allometry in T2 and T3 fish. Naeem et al. (2010) had also reported negative allometric increase in $\mathrm{Pb}$ with body weight in O. mykiss, although, Naeem et al. (2011) had discovered isometric increase of $\mathrm{Pb}$ with body weight in A. nobilis. These differences may be due to interspecific variations (Naeem et al., 2012b).

\section{Effect of Total length on elemental concentration}

Regression parameters revealed significant positive correlation for all metals, except for $\mathrm{K}, \mathrm{Mg}$ and $\mathrm{Pb}$ (T1), Fe (T1, T2) and Cd (T1, T2, T3) which showed non-significant positive relationship with total length. Naeem et al. (2011) in $\mathrm{Na}$ and Fe had reported highly significant correlation between elemental concentration and total length of the studied fish, while Salam et al. (1996) in O. niloticus documented no influence of total length on concentration of element composition, except for $\mathrm{Na}, \mathrm{K}, \mathrm{Sn}$ and $\mathrm{Pb}$ which showed positive allometry with total length. Naeem et al. (2010) had also reported highly significant correlation in $\mathrm{Na}$, $\mathrm{K}, \mathrm{Ca}, \mathrm{Zn}$ and $\mathrm{Pb}$ but non-significant relationship in $\mathrm{Mg}, \mathrm{Cd}, \mathrm{Cu}$ and $\mathrm{Mn}$ with total length in the studied O. mykiss. Similarly, Iqbal et al. (2019) observed non-significant relationship between all studied elements and total body length in hybrid (Catla catla $\mathrm{x}$ Labeo robita) fed on 15\%, 20\% and 25\% dietary protein levels. These variations, in the deposition of elements with increase in body length, may be the result of differences in fish species (Obot et al., 2016; Bawuro et al., 2018), fish age (Bawuro et al., 2018) and fish size (Naeem et al., 2011).

The present study revealed that all elements exhibited negative allometry, except for $\mathrm{Na}$ and $\mathrm{Pb}$ (T2) and Cd (T3) which showed isometric increase with total 
length. These results agree with those of Naeem et al. (2010) who had reported negative allometry (b < 3) in $\mathrm{Na}, \mathrm{K}, \mathrm{Ca}, \mathrm{Zn}$ and $\mathrm{Pb}$ in O. mykiss. although Naeem et al. (2011) had documented positive allometry in $\mathrm{Na} . \mathrm{K}, \mathrm{Ca}, \mathrm{Mg}, \mathrm{Fe}, \mathrm{Zn}, \mathrm{Cd}$ and $\mathrm{Pb}$ with total length in $A$. nobilis. Negative allometry in $\mathrm{Zn}$ and $\mathrm{Mg}$ in relation to total length in the present study is in agreement with results of Naeem et al. (2011) in female O. niloticus. Ansari et al. (2006) had also reported negative allometry in $\mathrm{Zn}$ and $\mathrm{Fe}$ with total length in Cirrbinus mrigala and Puntius chola, respectively similar to the findings of present study. Cadmium $(\mathrm{T} 1, \mathrm{~T} 2)$ and $\mathrm{Pb}(\mathrm{T} 1, \mathrm{~T} 3)$ indicated negative allometry with total length of sampled fish and this observation agrees with the opinion of Naeem et al. (2010). Isometric increase in $\mathrm{Cd}$ (T3) and $\mathrm{Pb}$ (T2) with total length is in line with Naeem et al. (2011). It is suggestive of some elements showing constant concentrations, while others exhibiting linear increase or decrease with the increase in the size of fish (Naeem et al., 2010), or being site-specific (Chatta et al., 2017) or species specific (Naeem et al., 2012a; Obot et al., 2016; Bawuro et al., 2018).

\section{Multiple regression analysis}

Application of multiple predictive equations for the determination of elemental concentrations from wet body weight and total length revealved that non-significant correlations were observed for most of the elements in the various treatment groups. Naeem et al. (2011) had reported non-significant correlation in $\mathrm{Ca}, \mathrm{Zn}, \mathrm{Cd}$ and $\mathrm{Pb}$ which agrees with the findings of present study: $\mathrm{Ca}$ (T1, T2), $\mathrm{Zn}$ (T2, T3), $\mathrm{Cd}$ and $\mathrm{Pb}$ (T2). Current study findings also showed significant correlations with $\mathrm{K}, \mathrm{Na}, \mathrm{Cd}, \mathrm{Fe}$ and $\mathrm{Pb}(\mathrm{T} 1, \mathrm{~T} 3), \mathrm{Zn}$ (T1) which is in agreement with the results of Naeem et al. (2010).

\section{Conclusions and Recommendations}

In the current investigation, graded dietary protein feed levels 15\% (T1), 20\% (T2) and 25\% (T3) showed their influence by increasing the concentrations of studied elements with increasing level of crude protein in the diet. The maximum concentrations of whole-body elements were displayed in fish fed with $25 \%$ crude protein diet (T3). Variations in the ranges of elemental concentration may be due to changes in ratios of feed ingredients in three feeds $(\mathrm{T} 1, \mathrm{~T} 2, \mathrm{~T} 3)$. A positive association between the elements and wet body weight as well as length of the sampled fish was investigated except for Fe in T1 with body weight. Predictive regression equations in the present study indicated that body size of studied GIFT showed its influence on the concentration of studied elements. As common trend of positive and negative allometry was observed for different elemental concentrations with fish body weight and total length. The level of non-essential toxic elements $\mathrm{Cd}$ and $\mathrm{Pb}$ has not exceeded the permitted levels of international standard. Further studies should be carried out in mono and polyculture in ponds instead of hapas to examine the impact of plant protein diets on elemental concentration of GIFT.

\section{Novelty Statement}

This study will be helpful for aquaculturists in the formulation of less expensive plant protein feeds and their no detrimental impact on fish health for the propagation of GIFT culture.

\section{Author's Contribution}

Anila Kousar performed experiment, did statistical analysis, and wrote the manuscript. Muhammad Naeem provided guidance for experimental layout, supervised the research work and helped in writing the manuscript. Samrah Masud helped in data analysis and writing the manuscript. Abir Ishtiaq helped in statistical analysis and reviewing of the manuscript. Zara Naeem helped in lab analysis. Rabia Iqbal assisted in lab work and statistical analysis of data.

\section{Conflict of interest}

The authors declare that they have no conflict of interest.

\section{References}

Abdel-Warith, A.W., N. Al-Asgah, Y. ElSayed, A. El-Otaby and S. Mahboob. 2018. The effect of replacement of fish meal with amino acids and optimized protein levels in the diet of the Nile Tilapia Oreochromis niloticus, Brazi. J. Biol., https://doi.org/10.1590/1519-6984.189413

Adaka, G., M. Ajima, C. Ezeafulugwe, D. Osuigwe, and A. Nlewadim. 2017. Assessment of heavy metals in fish tissues of some fish species in Oguta Lake, South-Eastern Nigeria. Futo J. Ser. 3(1): $249-257$.

Adamu, H.M., O.A.Ushie,E.Ogah, P.Y.Nkom and 
U. Usman. 2016. Uptake and risk assessment of heavy metals in vegetables grown in BayaraBauchi, Nigeria. Federal University Wukari. Trends Sci. Technol. J. 1(1): 50-54.

Adefemi, O. S. 2011. Chemical composition of Tilapia mosambis fish from major dams in EkitiState, Nigeria. Afri. J. Food Sci. 5(10): 550-554.

Adeyeye, E.I. 1996. Waste yield, proximate and mineral composition of three different types of land snails found in Nigeria. Int. J. Food Sci. Nut. 47: 111-116. https://doi. org/10.3109/09637489609012572

Agrahari, P., V.P. Singh, A. Singh, V.K. Singh and D.K. Singh. 2017. Atomic absorption spectroscopy detection of heavy metals $(\mathrm{Pb}, \mathrm{Hg}$, $\mathrm{As}, \mathrm{Cu}$ ) contamination in the water of natural Lakes of District Gorakhpur, U. P. India. J. Biol. Chem. Res. 34(2): 538547.

Ahmed, Q. L. Bat and Q. M. Ali. 2017. Bioaccumulation of nine heavy metals in some tissues of Anodontostoma chacunda (Hamilton, 1822) in the Arabian Sea coasts of Pakistan. NESciences. 2 (3): 79-92. https://doi. org/10.28978/nesciences.349296

Aldoghachi, M.A.J., M.M.A. Rahman, I. Yusoff and M.S. Azirun. 2016. Acute toxicity and bioaccumulation of heavy metals in red Tilapia fish. J. Anim. Plant Sci. 26(2): 507-513.

Al-Hafedh, Y.S.1999. Effects of dietary protein on growth and body composition of Nile tilapia, Oreochromis niloticus L. Aquacul. Res. 30: 385-393. https://doi.org/10.1046/j.13652109.1999.00343.x

Alhassan, A.B., M.L. Balarabe and I.M.K. Gadzama. 2016. Assessment of some heavy metals in macrobenthic invertebrate and water samples collected from Kubanni reservoir, Zaria, Nigeria. Federal University Wukari. Trends Sci. Technol. J. 1(1):55-60.

Ansari, T.M., M.A. Saeed, A. Raza, M. Naeem and A. Salam. 2006. Effect of body size on metal Concentrations in wild Puntius chola. Pak. J. Anal. Envi. Chem. 7(2): 116-119.

Ayeloja, A.A., F.O.A. George, A.Y. Shorinmade, W.A. Jimoh, Q.O. Afolabi and K.D. Olawepo. 2014. Heavy metal concentration in selected fish from Eleyele reservoir Ibadan Oyo State southwestern Nigeria. Afr. J. Environ. Sci. Technol. 8(7): 422-427. https://doi.org/10.5897/ AJEST2014.1700

Aziz, S., K. Saha, N. Sultana, H.P. Nur and
M.A. Ahsan. 2017. Comparative studies of elemental composition in leaves and flowers of Catharanthus roseus growing in Bangladesh. Asian Pac. J. Trop. Biomed.6: 50-54. https:// doi.org/10.1016/j.apjtb.2015.10.003

Bawuro, A. A., R. B. Voegborlo and A.A. Adimado. 2018. Bioaccumulation of heavy metals in some tissues of fish in lake Geriyo, Adamawa State, Nigeria. J. Environ. Public Health. Volume 2018, Article ID 1854892, 7 pages. https://doi. org/10.1155/2018/1854892

Bennett., A., P. Patil, K. Kleisner, D. Rader, J. Virdin and X. Basurto. 2018. Contribution of fisheries to food and nutrition security: Current knowledge, policy, and research. NI Report 1802. Durham, NC: Duke University.

Chatta, A.M., M.N. Khan, I. Hadyat, A. Asif and S.A. Naqvi. 2017. Detection of heavy metals (cadmium, lead and chromium) in farmed carp fish species, marketed at Lahore, Pakistan: A serious health concern for the consumers. Int. J. Biosci. 10(4): 199-211. https://doi. org/10.12692/ijb/10.4.199-211

Cheikyula, J.O., D. Torsabo, A.A. Garba, D.C. Abaver and M.A. Nasir. 2020. Growth Performance of Oreochromis niloticus Fingerlings Fed Varying Levels of Cassava Peel Meal as Replacement for Maize. J. Agric. Vet. Sci. 13 (1): 38-42.

Daniel, N. 2018. A review on replacing fish meal in aqua feeds using plant protein sources. Int. J. Fisher. Aqua. studies. 6: 164-179.

Das, S.S., M.K. Hossain, G.M. Mustafa, A. Parvin and B. Saha. 2017. Physicochemical properties of water and heavy metals concentration of sediments, feeds and various farmed Tilapia (Oreochoromis niloticus) In Bangladesh. Fish Aqua. J. 8(4): 232-239.

El-Serafy, S.S., M. E. Zowail, H. Nassr-Allah, N.H. Abdel-Hameid, M.H. Awwad and E.H. Omar. 2013. Effect of diet borne $\mathrm{Cu}$ and $\mathrm{Cd}$ on body indices of Nile Tilapia (Oreochromis niloticus) with emphasis on protein pattern. Turk. J. Fish. Aquat. Sci. 13: 593-602. https:// doi.org/10.4194/1303-2712-v13_4_04

El-Shehawy, S.M., A. Ali, A.A. Gab-Alla and H.M.A. Mutwally. 2016. Proximate and elemental composition of important fish species in Makkah Central Fish Market, Saudi Arabia. Food Nut. Sci. 7: 429-439. https://doi. org/10.4236/fns.2016.76044 
Food and Agriculture Organization (FAO). 1983. Compilation of legal limits for hazardous substances in fish and fishery products, FAO Fishery Circulars No. 764. Rome: 5-100.

Food and Agriculture Organization (FAO). 2010. Trace metals in environments. http://www.fao. org/trace metals.html

Hanan, S.G. 2007. Impact of certain heavy metals on the gills and liver of the Nile tilapia (Oreochromis niloticus). Egypt J. Aquat. Biol. Fish. 11(2): 79-100. https://doi.org/10.21608/ ejabf.2007.1936

Iqbal, R., M. Naeem and S. Masud. 2019. Effect of graded levels of dietary plant protein on elemental concentration (Catla catla ${ }^{\lambda}$ $\mathrm{x}$ Labeo robitaㅇ) from Pakistan. IJBPAS. 8(11): 2116-2127. https://doi.org/10.31032/ IJBPAS/2019/8.11.4857

Jaishankar, M., T. Tseten, N. Anbalagan, B.B. Mathew and K.N. Beeregowda. 2014. Toxicity, Mechanism and Health Effects of Some Heavy Metals. Interdiscipl. Toxicol. 7: 60-72. https:// doi.org/10.2478/intox-2014-0009

Jakhrani,M.A.,F.Z.,Dayo,M.Qasim, S.A.Jakhrani and A.A. Jakhrani. 2017. Elemental assessment in economically important Cirrbinus mrigala and Labeo rohita fish species captured from Indus River at Guddu Barrage, Sindh, Pakistan. Int.J. Sci. 6: 116-125. https://doi.org/10.18483/ ijSci. 1400

Jim, F., Garamumhango, P. and C. Musara. 2017. Comparative analysis of nutritional value of Oreochromis niloticus (Linnaeus), Nile tilapia, meat from three different ecosystems. J. Food Quality. Volume 2017. https://doi. org/10.1155/2017/6714347

Kalay, M., O. Ay and M. Canli. 1999. Heavy metal concentrations in fish tissues from the Northeast Mediterranean Sea. Bull. Environ. Contam. Toxicol. 63: 673-681. https://doi.org/10.1007/s001289901033

Langston, W.J.1990. Toxic effects of metals and the incidence of marine ecosystem, In: heavy metals in the Marine Environment (eds plmess, R.W. and Rainbow, P.S.), CAC press, New York. pp. 256.

Mannan, M.A., M.S. Hossain, M.A.A. Sarker, M.M. Hossain, L. Chandra, A.B.M.H. Haque and M. Kudrat-E-Zaha. 2018. Bioaccumulation of toxic heavy metals in fish after feeding with synthetic feed: A potential health risk in
Bangladesh. J. Nutr. Food Sci. 8: 728. https:// doi.org/10.4172/2155-9600.1000728

Merciai, R., H. Guascha, A. Kumara, S. Sabatera and E. Garcia-Bertho. 2014. Trace metal concentration and fish size: Variation among fish species in a Mediterranean river. Ecotoxicol. Environ. Saf. 107: 154-161. https://doi. org/10.1016/j.ecoenv.2014.05.006

Naeem, M., A. Salam, M.Y. Khokhar, M.F. Nasir, M.F. Nouman, A. Ishtiaq and R.A. Yar. 2012b. Evaluation of metal contents in female Oreochromis niloticus with emphasis on potential risk of consumption and relation to some biological aspects. Afri. J. Biotechnol. 10 (53): 11054-11057. https://doi.org/10.5897/ AJB11.1510

Naeem, M., Salam, A., N.T. Narejo, M.Y. Khokhar, R.A. Yar and A. Ishtiaq. 2012a. Heavy metal detection in Mystus bleekeri as bioindicator and potential risk of human health. Sindh Univ. Res. Jour. (Sci. Ser.). 44 (2): 189-194.

Naeem, M., A. Salam, S.S. Tahir and N. Rauf. 2010. Assessment of the essential elements and toxic heavy metals in hatchery reared Oncorbynchus mykiss. Int. J. Agric. Biol. 12: 935-938.

Naeem, N., A. Salam, S.S Tahir and N. Rauf. 2011. The effect of fish size and condition on the contents of twelve essential and non-essential elements in Aristichthys nobilis. Pak. Vet. J. 31(2): 109-112.

NIFES. 2016. The National Institute of Nutrition and Seafood Research. Undesirable Substances in Seafood.

Obot, O. I., A.I. Isangedighi and G.S. David. 2016. Heavy metals concentration in some commercial fishes in the lower cross River estury, Nigeria. Niger. J. Agric. Food Environ. 12(4): 218-223.

Olsson, P.E., P. Kling and C. Hogstrand. 1998. Mechanisms of heavy metal accumulation and toxicity in fish. In: Langston, W.J., Bebianno, M. J. (Eds.), Metal metabolism in Aquatic Environments, Chapman and Hall, London. pp. 321-350. https://doi.org/10.1007/978-14757-2761-6_10

Rajkowska, M. and M. Protasowicki. 2013. Distribution of metals (Fe, Mn, $\mathrm{Zn}, \mathrm{Cu}$ ) in fish tissues in two lakes of different trophy in Northwestern Poland. Environ. Monit. Assess. 185: 3493-3502. https://doi.org/10.1007/ s10661-012-2805-8 
Radhakrishnan, S., P.S. Bhavan, C. Seenivasan and T. Muralishankar. 2016. Impact of fishmeal replacement with Arthrospira platensis on growth performance, body composition and digestive enzyme activities of the freshwater prawn, Macrobrachium rosenbergii. Aquacult. Res. 3: 35-44. https://doi.org/10.1016/j. aqrep.2015.11.005

Roy, U.S., B. Chattopadhyay, S. Datta and S.K. Mukhopadhyay. 2011. Metallothionein as a biomarker to assess the effects of pollution on Indian major carp species from waste water-fed fish ponds of East Calcutta wetlands (a Ramsar Site). Environ. Engin. Manag. J. 4: 10-17.

Salam, A., T.M. Ansari and Q.A. Akhtar. 1993. Studies on the effect of body size on whole body elemental concentration of farmed rohu, Labeo rohita (Ham.) from Multan. Pakistan. Proc. Pakistan Cong. Zool. 13: 467-472.

Salam, A., T.M. Ansari and Q.A. Akhtar. 2002. Effect of body size on metal concentrations in farmed Cirrbinus mrigala. Asian Fish. Sci., 15: 329-334.

Salam, A., M. Naeem, T.M. Ansari, J.A. Mahmood and N. Tariq. 1996. Effect of body size on trace metal concentration in hatchery reared Oreochromis nilotica. Biologia. 42: 19-26.

Shearer, K.D. 1984. Changes in the elemental composition of hatchery reared Rainbow trout, Salmo gairdneri, associated with growth and reproduction. Can. J. Fish. Aquat. Sci. 41: 15921600. https://doi.org/10.1139/f84-197

Shovon, M.N.H., B.C. Majumdar and Z. Rahman. 2017. Heavy Metals (Lead, Cadmium and Nickel) concentration in deferent organs of three commonly consumed fishes in Bangladesh. Fish Aqua. J. 8: 20-27.

Soetan, K.O., C.O. Olaiya and O.E. Oyewol. 2010. The importance of mineral elements for humans, domestic animals and plants: A Review. Afri. J. Food Sci. 4: 200-222.

Sthanadar, I.A., A.A. Sthanadar, B. Begum, M.J. Nair, I. Ahmad, A. Muhammad, M. Zahid and S. Ullah. 2015. Aquatic pollution assessment using skin tissues of mulley (Wallago attu,
Bloch and Schneider, 1801) as a bio-indicator in Kalpani river at District Mardan, Khyber Pakhtunkhwa, Pakistan. J. Biodiv. Environ. Sci. 6(2): 57-66.

Tsegay, T., P. Natarajan and T. Zelealem. 2016. Analysis of diet and biochemical composition of Nile tilapia (Oreochromis niloticus) from Tekeze Reservoir and Lake Hashenge, Ethiopia. J. Fish. Livest. Prod. 4(2): 172-178. https://doi. org/10.4172/2332-2608.1000172

Turchini, G.M.,J.T.Trushenski and B.D. Glencross. 2019. Toughts for the future of aquaculture nutrition: realigning perspectives to reflect contemporary issues related to judicious use of marine resources in aquafeeds. North Am. J. Aquacult. 8: 13-39. https://doi.org/10.1002/ naaq. 10067

WHO. 1995. World Health Organization, Inorganic lead. Environmental health criteria number 165, Geneva.

Widianarko, B., C.A.M. Van Gestel, R.A. Verweij and N.M. Van Straalen. 2000. Associations between trace metals in sediment, water, and guppy, Poecilia reticulate (Peters), from urban streams of Semarang, Indonesia. Ecotox. Environ. Safe. 46: 101-107. https://doi. org/10.1006/eesa.1999.1879

Yamazaki, M., Y. Tanizak and T. Shimokawa. 1996. Silver and other trace elements in a freshwater fish, Carasius auratus langsdorfii, from the Asakawa River in Tokyo, Japan. Environ. Pollut. 94: 83-90. https://doi.org/10.1016/S02697491(96)00053-X

Yousaf, M., A. Salam, M. Naeem and M.K.Y. Khokhar. 2012. Effect of body size on elemental concentration in wild Wallago attu (Bloch and Schneider) from southern Punjab, Pakistan. Afr. J. Biotechnol.11(7): 1764-1767. https:// doi.org/10.5897/AJB11.722

Zettl, S., D. Cree, M. Soleimani and L. Tabil. 2019. Mechanical properties of aquaculture feed pellets using plant-based protein. Cogent Food and Agricult. 5(1): 1656917. https://doi.org/10. 1080/23311932.2019.1656917 